\title{
Implementation of Combination of Simple Additive Weighting (SAW) and Analytical Hierarchy Process (AHP) Method to Determine Employee Salary Increase in PT. Spring Island Travel
}

\author{
$1^{\text {st }}$ Muhardi Saputra \\ Department of Information System \\ Universitas Prima Indonesia \\ Medan, North Sumatera
}

\author{
$2^{\text {nd }}$ Siti Aisyah \\ Department of Information System \\ Universitas Prima Indonesia \\ Medan, North Sumatera
}

\author{
$3^{\text {rd }}$ Jesslyn Josephine \\ Department of Information System \\ Universitas Prima Indonesia \\ Medan, North Sumatera
}

\author{
$4^{\text {th }}$ Intan Gartiwi \\ Department of Computer System \\ Universitas Prima Indonesia \\ Medan, North Sumatera
}

\author{
$5^{\text {th }}$ Syahril Khairi Hasibuan \\ Department of Information System \\ Universitas Prima Indonesia \\ Medan, North Sumatera
}

\begin{abstract}
Decision Support System (SPK) is generally defined as a system that is able to provide both the ability to solve problems and the ability to communicate to semi-structured problems. Salary is an important factor in the company in order to provide salaries to employees who have worked in the company, salary increases are in order to improve employee performance better and see the performance of employees who work well. The method used in this study is the SAW and AHP method, where the basic concept of the SAW method is to find the weighted sum of the performance ratings on each alternative for all attributes while the basic concept of the AHP method is to describe a complex multi-factor or multi-criteria problem into a hierarchy. In designing the system, the authors do the design using Visual Basic 2008 and SQL Server 2008 databases. The benefits obtained from the design of the system are able to facilitate the company in determining which employees deserve an employee salary increase.
\end{abstract}

Keyword:- Decision Support System, Increase Employee Salary, SAW Method, AHP Method, Visual Basic 2008, SQL Server 2008

\section{INTRODUCTION}

Decision Support System (Decision Support System) is a system intended to support material decision makers in a semi-structured decision situation[1]. DSS is intended to be a tool for decision makers to expand their capabilities, but not to replace their judgment.

The Simple Additive Weighting (SAW) method is often known as the weighted sum method. The basic concept of the SAW method is to find a weighted sum of the performance ratings for each alternative on all attributes[2].
Analytical Hierarchy Process (AHP) method is a method for making an alternative order of decisions and choosing the best alternative when making decisions with several criteria for making certain decisions.

PT. Spring Island Travel is a company engaged in the field of ticket sales in the city of Medan. PT. Spring Island Travel has been around for a long time. In the management of quite a lot of employees, then there are obstacles that occur when calculating the salary increase of employees of PT. Spring Island Travel. Therefore there is a need for a system that can support the decision making of salary increases for each employee.

Based on the description above in outline presented in the form of a thesis report with the title "Implementation of the Combination of Simple Additive Weighting (SAW) Method and Analytical Hierarchy Process (AHP) Method to Determine the Increase in Employee Salaries at PT. Spring Island Travel ".

The scope of the problem, in particular the identification of problems made by the author is Implementing the SAW method and the AHP method to determine employee salary increases at PT. Spring Island Travel. Company process data is still using manual method.

Based on the background of the problems mentioned above, a number of problems can be identified, including Determining employee salary increases. Implement the SAW method and the AHP method to determine employee salary increases. Implement the SAW method and the AHP method in Visual Basic 2008 and SQL Server 2008 applications.

Given the extent of the problem, the authors make the following problem boundaries. The study focuses only on 
ISSN No:-2456-2165

determining employee salary increases. The data used as input to the system is the calculation of salary increase for employees taken from PT. Spring Island Travel. The method used in this design is the Simple Additive Weighting (SAW) method and the Analytical Hierarchy Process (AHP) method. Using the Visual Basic 2008 programming language and as a database using SQL Server 2008.

The criteria used are based on aspects of employee attendance, discipline, performance appraisal, education status, length of work and class of work.

The purpose and objectives of this study are to implement a decision support system that can help in the decision to increase employee salaries with the SAW method and the AHP method. Designing a decision support system application in determining the amount of salary increase for each employee using the SAW method and the AHP method. Implement a decision support system to help determine employee salary increases with the SAW method and the AHP method.

The benefits of this research are the Application of Decision Support Systems using the SAW method and the AHP method can find out the amount of employee salary increases[3]. Simplify and speed up performance on determining the amount of employee salary increases. The process of determining the amount of employee salary increases can be done quickly and accurately.

The basic concept of the SAW method is to find a weighted sum of the performance ratings for each alternative on all attributes. The SAW method requires the decision matrix normalization process.

(X) to a scale that can be compared with all existing alternative ratings (Memariani, 2009). This method is the most widely used method in dealing with Multiple Attribute Decision Making (MADM) situations.

Simple Additive Weighting (SAW) is one method for multi-attribute decision making. This is used to determine the best alternative from various alternatives (Rahmawati et al, 2013). Scoring with this method is obtained by adding contributions from each attribute (Kahraman et al. 2003).

Analytical Hierarchy Process (AHP) is a general theory of measurement used to find the ratio scale, both from discrete and continuous pair comparisons (Singh, 2016).

\section{RESEARCH METHOD}

The criteria must have a priority scale (scale of influence) to get a decision support for employee salary increases $^{[4]}$. The priority scale of the criteria is obtained by conducting a survey with one of the employees at PT. Spring Island Travel. The results of the interview can be seen in Table 1 below.

\begin{tabular}{|c|c|}
\hline Criteria & Priority Scale \\
\hline Performance & Very Priority \\
\hline Discipline & Very Priority \\
\hline Attendance & Very Priority \\
\hline Length of work & Priority \\
\hline Educational status & Priority \\
\hline Class of work & Quite Priority \\
\hline
\end{tabular}

Table 1:- Priority Scale Against Criteria

Determination of the value of criteria weights is determined by the decision maker with the criteria $\mathrm{C} 1, \mathrm{C} 2$ and $\mathrm{C} 3$ is a highly priority effect then given the highest value. Criteria C4 and C5 are priority effects and C6 criteria have sufficient priority effect. The total weight if added together the overall criteria is $100 \%$.

Based on the two journals from the research of Adriyendi and Azizollah Memariani, the authors determined the value of the criteria weights as in table 2 .

\begin{tabular}{|c|c|c|c|}
\hline Criteria & Priority Scale & $\begin{array}{c}\text { Integrity } \\
(\%)\end{array}$ & $\begin{array}{c}\text { Integrity } \\
\text { (Conversion) }\end{array}$ \\
\hline Performance & Very Priority & 20 & 0.20 \\
\hline Discipline & Very Priority & 20 & 0.20 \\
\hline Attendance & Very Priority & 20 & 0.20 \\
\hline Length of work & Priority & 15 & 0.15 \\
\hline Educational status & Priority & 15 & 0.15 \\
\hline Class of work & Quite Priority & 10 & 0.10 \\
\hline \multicolumn{2}{|c|}{ TOTAL } & 100 & 1.00 \\
\hline
\end{tabular}

Table 2:- Criteria Weight

The merger of the Analytical Hierarchy Process (AHP) method to the Simple Additive Weighting (SAW) method with the process flow is the determination of the value of the criteria weight by the AHP method process then the determination of decision support with the SAW method process.

The steps to look for the criteria weight value using the AHP method, namely:

a. Search for eigen vector values

The eigen vector value search first performs a comparison of criteria.

\begin{tabular}{|c|c|c|c|c|c|c|}
\hline Criteria & K1 & K2 & K3 & K4 & K5 & K6 \\
\hline Performance & 1 & 1 & 1 & 3 & 3 & 5 \\
\hline Discipline & 1 & 1 & 1 & 3 & 3 & 5 \\
\hline Attendance & 1 & 1 & 1 & 3 & 3 & 5 \\
\hline Length of work & $1 / 3$ & $1 / 3$ & $1 / 3$ & 1 & 1 & 3 \\
\hline Educational status & $1 / 3$ & $1 / 3$ & $1 / 3$ & 1 & 1 & 3 \\
\hline Class of work & $1 / 5$ & $1 / 5$ & $1 / 5$ & $1 / 3$ & $1 / 3$ & 1 \\
\hline
\end{tabular}

Table 3:- Scale of Criteria Comparison 
Table 3 explains that the scale comparison between criteria. For example the attendance criteria. Then do the column addition of the comparison criteria:

\begin{tabular}{|c|c|c|c|c|c|c|}
\hline Criteria & K1 & K2 & K3 & K4 & K5 & K6 \\
\hline Performance & 1 & 1 & 1 & 3 & 3 & 3 \\
\hline Discipline & 1 & 1 & 1 & 3 & 3 & 5 \\
\hline Attendance & 1 & 1 & 1 & 1 & 1 & 3 \\
\hline Length of work & 0.333 & 0.333 & 0.333 & 1 & 1 & 3 \\
\hline Educational status & 0.333 & 0.333 & 0.333 & 0.333 & 0.333 & 1 \\
\hline Class of work & 0.2 & 0.2 & 0.2 & 11.333 & 11.333 & 22 \\
\hline TOTAL & 3.866 & 3.866 & 3.866 & & & 5 \\
\hline
\end{tabular}

Table 4:- Sum of Columns

Then the division is done. Each element is divided by the number of each column. Can be seen in table 5 .

\begin{tabular}{|c|c|c|c|c|c|c|}
\hline Criteria & K1 & K2 & K3 & K4 & K5 & K6 \\
\hline Performance & 0.2587 & 0.2587 & 0.2587 & 0.2647 & 0.2647 & 0.2273 \\
\hline Discipline & 0.2587 & 0.2587 & 0.2587 & 0.2647 & 0.2647 & 0.2273 \\
\hline Attendance & 0.2587 & 0.2587 & 0.2587 & 0.2647 & 0.2647 & 0.2273 \\
\hline Length of work & 0.0861 & 0.0861 & 0.0861 & 0.0882 & 0.0882 & 0.1364 \\
\hline Educational status & 0.0861 & 0.0861 & 0.0861 & 0.0882 & 0.0882 & 0.1364 \\
\hline Class of work & 0.0517 & 0.0517 & 0.0517 & 0.0294 & 0.0294 & 0.0455 \\
\hline
\end{tabular}

Table 5:- Devion of Elements

\begin{tabular}{|c|c|c|c|c|c|c|c|}
\hline Criteria & K1 & K2 & K3 & K4 & K5 & K6 & TOTAL \\
\hline Performance & 0.2587 & 0.2587 & 0.2587 & 0.2647 & 0.2647 & 0.2273 & 1.5328 \\
\hline Discipline & 0.2587 & 0.2587 & 0.2587 & 0.2647 & 0.2647 & 0.2273 & 1.5328 \\
\hline Attendance & 0.2587 & 0.2587 & 0.2587 & 0.2647 & 0.2647 & 0.2273 & 1.5328 \\
\hline Length of work & 0.0861 & 0.0861 & 0.0861 & 0.0882 & 0.0882 & 0.1364 & 0.5711 \\
\hline Educational status & 0.0861 & 0.0861 & 0.0861 & 0.0882 & 0.0882 & 0.1364 & 0.5711 \\
\hline Class of work & 0.0517 & 0.0517 & 0.0517 & 0.0294 & 0.0294 & 0.0455 & 0.2594 \\
\hline
\end{tabular}

Table 6:- Sum of Rows

After the number of rows is obtained, the next is to divide the number of criteria. The number of criteria in this study is 6 (six). The results obtained are called eigen vectors.

\begin{tabular}{|c|c|}
\hline Number of Lines / Many Criteria & Eigen Vector \\
\hline $1.5328 / 6$ & 0.2555 \\
\hline $1.5328 / 6$ & 0.2555 \\
\hline $1.5328 / 6$ & 0.2555 \\
\hline $0.5711 / 6$ & 0.0952 \\
\hline $0.5711 / 6$ & 0.0952 \\
\hline $0.2594 / 6$ & 0.0432 \\
\hline
\end{tabular}

Table 7:- Eigen Vector

\section{b. Search for consistency value}

Search for consistency value is a search to find out whether the comparison of criteria performed is correct or not or the eigenvector value has an absolute value or not.

\begin{tabular}{|c|c|c|c|c|c|c|c|c|c|c|c|c|c|c|}
\hline Size & 1,2 & 3 & 4 & 5 & 6 & 7 & 8 & 9 & 10 & 11 & 12 & 13 & 14 & 15 \\
\hline $\begin{array}{l}\text { Random } \\
\text { Index }\end{array}$ & 0.00 & 0.58 & 0.90 & 1.12 & 1.24 & 1.32 & 1.41 & 1.45 & 1.49 & 1.51 & 1.48 & 1.56 & 1.57 & 1.59 \\
\hline
\end{tabular}

Table 8:- Table of Random Index (RI) 
c. Results

After searching for the CR value and CR value not greater than 0.1 , the absolute eigenvector value of consistency and comparison scale are correct. So the eigenvector value is used as a weighting criterion in the SAW method.

\begin{tabular}{|c|c|c|c|}
\hline Criteria & Priority Scale & Integrity (\%) & Integrity (Conversion) \\
\hline Performance & Very Priority & 25.55 & 0.2555 \\
\hline Discipline & Very Priority & 25.55 & 0.2555 \\
\hline Attendance & Very Priority & 25.55 & 0.2555 \\
\hline Length of work & Priority & 9.52 & 0.0952 \\
\hline Educational status & Priority & 9.52 & 0.0952 \\
\hline Class of work & Quite Priority & 4.32 & 0.0432 \\
\hline \multicolumn{2}{|c|}{ TOTAL } & 100 & 1.00 \\
\hline
\end{tabular}

Table 9:- Criteria Weights

In the selection process the determination of employee salary increases at PT. Spring Island Travel. The research steps for designing Simple Additive Weighting (SAW) are as follows:

\section{Determine variables}

\begin{tabular}{|c|c|c|}
\hline No & Function & $\mathbf{V}$ \\
\hline 1 & \multirow{6}{*}{ Input } & Attendance \\
\hline 2 & & Discipline \\
\hline 3 & & Performance \\
\hline 4 & & Length of Work \\
\hline 5 & & Educational Status \\
\hline 6 & & Class of Work \\
\hline 7 & Output & $\begin{array}{c}\text { Produce an optimal and accurate preference } \\
\text { value as determining } \\
\text { employee salary increases }\end{array}$ \\
\hline
\end{tabular}

Table 10:- Variables

\section{Look for the value of weights on the criteria}

Determination of the weight value of the criteria plays an important role in determining the decision of the SAW method.

\section{The search for normalized values}

The search for normalized values in the SAW method is determining the max or min values according to the criteria requirements first.

\begin{tabular}{|c|c|c|c|c|c|c|}
\hline Altf & K1 & K2 & K3 & K4 & K5 & K6 \\
\hline A1 & 1 & 1 & 89 & 1 & 1 & 1 \\
\hline A2 & 1 & 1 & 83 & 1 & 1 & 3 \\
\hline A3 & 1 & 1 & 84 & 0 & 1 & 2 \\
\hline A4 & 0 & 1 & 80 & 0 & 0 & 2 \\
\hline A5 & 1 & 1 & 77 & 1 & 0 & 2 \\
\hline A6 & 1 & 1 & 86 & 0 & 0 & 2 \\
\hline A7 & 0 & 1 & 78 & 0 & 0 & 1 \\
\hline A8 & 1 & 1 & 85 & 0 & 0 & 3 \\
\hline A9 & 1 & 1 & 84 & 0 & 0 & 1 \\
\hline A10 & 1 & 1 & 79 & 1 & 0 & 3 \\
\hline Max & 1 & 1 & 89 & 1 & 1 & 1 \\
\hline Min & - & - & - & - & - & - \\
\hline
\end{tabular}

Table 11:- Max and Min Values

\begin{tabular}{|c|c|c|c|c|c|c|}
\hline Altf & K1 & K2 & K3 & K4 & K5 & K6 \\
\hline A1 & 1 & 1 & 1 & 1 & 1 & 1 \\
\hline A2 & 1 & 1 & 0.93 & 1 & 0.40 & 0.33 \\
\hline A3 & 1 & 1 & 0.94 & 0 & 0.40 & 0.50 \\
\hline A4 & 0 & 1 & 0.90 & 0 & 0.37 & 0.50 \\
\hline A5 & 1 & 1 & 0.87 & 1 & 0.33 & 0.50 \\
\hline A6 & 1 & 1 & 0.97 & 0 & 0.33 & 0.50 \\
\hline A7 & 0 & 1 & 0.88 & 0 & 0.28 & 1 \\
\hline A8 & 1 & 1 & 0.96 & 0 & 0.23 & 0.33 \\
\hline A9 & 1 & 1 & 0.94 & 0 & 0.20 & 1 \\
\hline
\end{tabular}

Table 12:- Normalization Value

\section{Search for preference values}

Search for preference value is the calculation of the last part of the Simple Additive Weighting method.

\section{RESULTS}

Then the result of the preference of the Simple Additive Weighting method to alternatives V1 to V10 can be seen in table 13 .

\begin{tabular}{|c|c|}
\hline V & Result \\
\hline V1 & 1.0000 \\
\hline V2 & 0.8290 \\
\hline V3 & 0.6980 \\
\hline V4 & 0.4855 \\
\hline V5 & 0.8235 \\
\hline V6 & 0.6935 \\
\hline V7 & 0.5180 \\
\hline V8 & 0.6595 \\
\hline V9 & 0.7180 \\
\hline V10 & 0.7910 \\
\hline
\end{tabular}

Table 13:- Results Preferences of the SAW Method

The author makes an employee salary increase category that is if the final value (preference) of each alternative is above 0.70 then the good category. And if the final value (preference) for each alternative is below 0.70 then the category is not good. 


\begin{tabular}{|c|c|c|c|c|c|}
\hline \multicolumn{3}{|c|}{ SAW } & \multicolumn{3}{c|}{ SAW-AHP } \\
\hline Altf & Result & Status & Altf & Result & Status \\
\hline A1 & 1.0000 & Bagus & A1 & 1.0001 & Bagus \\
\hline A2 & 0.8290 & Bagus & A2 & 0.8962 & Bagus \\
\hline A3 & 0.6980 & Kurang & A3 & 0.8109 & Bagus \\
\hline A4 & 0.4855 & Kurang & A4 & 0.5423 & Kurang \\
\hline A5 & 0.8235 & Bagus & A5 & 0.8815 & Bagus \\
\hline A6 & 0.6935 & Kurang & A6 & 0.8118 & Bagus \\
\hline A7 & 0.5180 & Kurang & A7 & 0.5502 & Kurang \\
\hline A8 & 0.6595 & Kurang & A8 & 0.7925 & Bagus \\
\hline A9 & 0.7180 & Bagus & A9 & 0.8134 & Bagus \\
\hline A10 & 0.7910 & Bagus & A10 & 0.8669 & Bagus \\
\hline
\end{tabular}

[6]. Susanto, A. (2013). Sistem Informasi Akuntansi. Lingga Jaya. Bandung.

[7]. Wilman, R. R.. 2013. Mengenali dan Mengatasi Kerusakan Software. Handphone. PT Kawan Pustaka, Tangerang.

[8]. Komputer, W. (2014), PHP Programming. Andi, Semarang.

[9]. Aqib, Z. (2013). Model-model, Media, dan Strategi Pembelajaran Kontekstual (Inovatif). Yrama Widya. Bandung.

[10]. Argono, (2011), Pengertian Software, http://xlsolution.blogspot.com/-2011/12/softwarebkbp- bimbingan-konseling.html, Diakses pada tanggal 12 Mei 2018

in Employee Salary

From table 14 it is known that there is a big difference between SAW and SAW-AHP on the number of salary increases status of good category employees. From the SAW method, there are 5 alternatives of employee salary increase status in the good category, while the SAW-AHP has 8 alternative status for the employee salary increase in the good category.

\section{CONCLUSION}

Based on the research that has been done, the following conclusions can be drawn: Analysis of the search for the weight value of the Simple Additive Weighting (SAW) method and the Simple Additive Weighting (SAW) method by using the Analytical Hierarchy Process (AHP) method calculation results in different criteria weighting values. Different weight values result in different decision making results too. The SAW-AHP combination provides more accurate and selective results. Giving a weighting value to the criteria in the Simple Additive Weighting (SAW) method is only based on the decision maker without further analysis as in the Analytical Hierarchy Process (AHP) method. This causes the Simple Additive Weighting (SAW) method to lack the selection of decision support systems. A large preference value causes the selection is not optimal.

\section{REFERENCES}

[1]. Kusrini. (2014). Konsep dan Aplikasi Sistem Pendukung Keputusan. Yogyakarta : Penerbit Andi.

[2]. Ladjamudin, B. A. B. (2010), Analisis dan Desain Sistem Informasi, Tangerang : Penerbit Graha Ilmu.

[3]. Istianingsih. (2012). Pengaruh Pengguna Sistem Informasi Terhadap Kinerja Individu (Studi Empiris Pada Pengguna Paket Program Aplikasi Sistem Informasi Akuntansi Di Indonesia). Jurnal Fakultas Ekonomi Universitas Mercubuana.

[4]. Jogiyanto, H. (2014). Metode Penelitian Bisnis. Edisi Ke-6. Universitas Gadjah Mada. Yogyakarta.

[5]. Satzinger, J. B. (2012). "System Analisis and Design with the Unified. Process". USA: Course Technology, Cengage Learning. 